\title{
GIS Applications for Assessing Spatial Distribution of Boreholes and Hand Dug Wells in Boroboro Community, Atiba Local Government, Oyo State
}

\author{
Olagoke Emmanuel Awodumi* and Opeyemi Stephen Akeasa ${ }^{2}$
}

Department of Geographic Information System, Federal School of Surveying, Oyo, Oyo State, Nigeria

\begin{abstract}
Shortage of water supply and quality has become a major global concern as a result of rapid population growth; industrial activities, agricultural expansion and currently climate change. As urbanization increases, so thus, human consumption and demand for water continue increases. Boroboro community is a sub-urban settlement which has a major challenge in supply of water because of limited number of boreholes and hand-dug wells as well as effect of season variation in the community. This research is aimed at mapping and assessing the spatial distribution of boreholes and hand-dug wells in Boroboro community using Geographical Information Systems (GIS). The spatial distribution of the boreholes and hand dug wells were determined using hand-held GPS. The data generated was analyzed using ArcGIS 10.3 software and the buffering of the boreholes and hand-dug wellswere overlaid to know those who have access to both the boreholes and the hand dug well. The result shows as the community expands, the distance to the existing and available boreholes and hand dug wells increases. It is recommended government should assist in the provision of potable water through sitting of hand dug wells and boreholes with good depth in the study area.
\end{abstract}

Keywords: Climate; Geographical; Water; Boreholes

\section{Introduction}

Water is vital for man's existence and without it there would be no life on earth. It is an important resource to any nation who is committed to its effectiveness in terms of planning, development, conservation, distribution and management in order to avoid future water problems. The total water requirement is on the increase and the per capita water consumption is also on the increase due to the increase in population and civilization [1]. Several successive governments in Nigeria at the Federal, state and local levels have made frantic efforts to provide portable and adequate water supply to its citizen. These strides of water supply services, where they exist are unreliable, and not sustainable because of obvious difficulties in management. In the light of this, the World Bank [2] stated that one of the key issues emerging in our time is access to clean water. It is estimated that just $12 \%$ of the global population consumes $86 \%$ of the available water while 1.1 billion people (one sixth of the world's population) has no access to adequate water supplies. As global demand for clean water is increasing, changes in climate and pollution are reducing potable raw water. This leads to an emerging interest in improving safe water access through small-scale water projects at the household, (provision of personal water boreholes) to arrest the problems posed by water crisis [3]. Well log (borehole and hand dug wells) data of exiting nearby boreholes and hand dug wells had overtime served as the most reliable source of data of the lithostratigraphic sequence of subsurface [4]. A recent development saw the application of GIS technology. Although cost implication of GIS may seem to be high, it has potential to give supported project costing of hydro-geology exploration and development and project in the future. The ability of GIS displays the number of unconnected data sets, bringing them into the common reference system for spatial analysis from which relationships can be identified and decisions and spatial set of the study area will be made [5]. There is need for proper assessment. The demand for water has been on the increase while the supply has been so low in Boroboro community that it hardly serves the people of the town. It was observed during the site visiting that only the borehole drilled by Atiba Local Government and one from Islamic group were found in the community. This reveals an obvious shortage of potable borehole water in the community. This among others calls for assessment of spatial distribution of hand dug well and borehole water to effectively meet the demand of the people of Boroboro community and its environs.

The aim and objectives of this study is to assess the hand dug wells and boreholes water supply in Boroboro community and its environ using GIS. Specifically, the study seeks to:

a) design a spatial database for the study area

b) map the existing spatial distribution of hand dug wells and boreholes in the study area

c) determine the coverage area of boreholes and well with respect to building in the study area

d) determine areas that lack access to both the hand dug well and boreholes in the study area.

Creation of spatial database for the assessment and evaluation of boreholes and hand dug well is expected to aid the production of geospatial information that could serve as decision support system for borehole distribution in the study area so as to reduce the problem of inadequate supply of quality drinking water thereby reducing the scourge of waterborne disease most especially cholera and to improve the quality of life of people in the community.

\section{Literature Review}

The past and the present experience of the people in the study area in the area of water supply are nothing to write home about. This is because people search for water day and night shortly after the rainy

*Corresponding author: Olagoke Emmanuel Awodumi, Department of Geographic Information System, Federal School of Surveying, Oyo, Oyo State, Nigeria, Tel: 08159464640; E-mail: gokeemmanuel@gmail.com

Received July 28, 2017; Accepted August 21 2017; Published August 23, 2017

Citation: Awodumi OE, Akeasa OS (2017) GIS Applications for Assessing Spatia Distribution of Boreholes and Hand Dug Wells in Boroboro Community, Atiba Local Government, Oyo State. J Remote Sensing \& GIS 6: 208. doi: 10.4172/24694134.1000208

Copyright: $\odot 2017$ Awodumi OE, et al. This is an open-access article distributed under the terms of the Creative Commons Attribution License, which permits unrestricted use, distribution, and reproduction in any medium, provided the original author and source are credited. 
Citation: Awodumi OE, Akeasa OS (2017) GIS Applications for Assessing Spatial Distribution of Boreholes and Hand Dug Wells in Boroboro Community, Atiba Local Government, Oyo State. J Remote Sensing \& GIS 6: 208. doi: 10.4172/2469-4134.1000208

Page 2 of 17

season. Increasingly, greater variability in climate may be exacerbating the problems of water supply in adequate quantities and of acceptable quality in the developing world [6]. Water scarcity is a concern to most Sub-Saharan African. The United Nations Environmental Programme (UNEP) estimates that 250 million people in Africa will be at risk of water stress, less than $1700 \mathrm{M}^{3}$ of water available per person per year by 2020 and up to 500 million by 2050 [7]. Sub- Saharan Africa is making the slowest progress in meeting the MDGs target as one-third of its population still need safe drinking water [8]. Previous study have shown that water tends to be store in the fracture basement aquifers in the study are because of the thin overburden which rarely retains water was surplus in study area. Groundwater exploration success rated very low in basement complex due to in appropriate exploration or interpretation method resulting from an incomplete understanding of the geo-hydrology. Most wells in the basement complex dries up shortly before or during dries season hence leaving the inhabitants to suffer scarcity of water. This can be attributed to lowering of the water table at this period because the rate of discharge is less than the rate of extraction of water from the aquifers. If over a period of time, groundwater withdrawal rates consistence exceeds recharge rate, the regional water table may drop [9]. The traditional method of obtaining ground water in rural areas of the developing world and still the most common is by means of hand-dug wells. However, because they are dug by had there are use is restricted to suitable types of ground, such as clays, sands, gravel and mixed soils where only small boulders are encountered. Some communities use the skill and knowledge of well diggers, but often the excavation is carried out, under supervision, by the villages themselves. The volume of the water in the well below the standing water table act as a reservoir which can meet demands on it is during the day and should replenish itself during period when there are no abstractions. Previous studies show that the hand-dug wells and borehole drilled in the various communities are majorly owned by individuals, and majority have no access to the borehole and prefer to drink the well water as alternative.

\section{Methodology}

This is the step by steps taken to achieve aim and objectives of the project. The techniques used in carrying out the research are data acquisition, processing and information presentation. Spatial data display an important role in any Geographic information system study, the primary source of the data collection was based on field survey which involved the collection of borehole coordinates using hand held GPS (Garmin 79), measuring tape suspended with an iron rod to know the depth of water and interview was conducted to the occupants of the building. Sematic data about the well are also gathered using Focus Group Discussion Secondary data were also sourced from previous maps and satellite imagery copy of the research area.

The GIS analyses adopted in the real world are:

- Buffering operation (200 m hand dug wells and boreholes coverage),

- Retrieval (spatial query),

- overlay operation,

- union (buffered $200 \mathrm{~m}$ hand dug wells and boreholes).

\section{Study area}

Boroboro community is located in the eastern part of oyo town in Atiba local Government Oyo state, Nigeria. With Latitude $36.1535^{\circ} \mathrm{N}$, Longitude $86.7958^{\circ} \mathrm{W}$. The major language speaks is Yoruba. Oyo town is located in the North of Ibadan, the capital city of Oyo State and lies between latitude $7^{\circ} .8^{\prime} 33^{\prime \prime} \mathrm{N}$ and $7^{\circ} .9^{\prime} 33^{\prime \prime} \mathrm{N}$ and longitude $3^{\circ} .8^{\prime} 67^{\prime \prime} \mathrm{E}$ and $4^{\circ} .0^{\prime} 00^{\prime \prime} \mathrm{E}$.

Geologic setting of the area: The study area is located within the basement complex of south - western Nigeria. The Basement complex of Nigeria is made up of only Precambrian of late Proterozoic rocks, which occur in West African creation. The Geology comprises of a fold belt which is one of the major indication of deformation during the late Precambrian age in Nigeria. It trends from the NNS to SSE and covers a large area of about $200 \mathrm{~km}^{2}$. The rocks are mainly of crystalline rocks such as migmatites, gneiss and a meta-supracrustal sequence associated with fault zone [10]. Base on the petrography, lithological criteria and the classification of the basement complex of Nigeria, Rahaman [11] recognized the following units within the basement complex of Nigeria:

- Migmatites Gneiss Complex of paleoprotozoic age,

- The Older Granite pan Africa orogeny of 600 ma,

- Charnokitic rocks,

- Unmetamorphosed dolerite dykes,

- The schist belt of paleoprotozoic and neoprotozoic age.

Rock expose are not observed in the basement of this nature, underground water is restricted to the overburden (earth) and fracture zones underlying the basement rock below and overburden (Figure 1).

\section{Logical design}

The logical model is an implementation-oriented representation of reality that is often expressed in the form of diagrams and lists. Kufoniyi [12] stated that, it is at the logical design phase that the choice of data structure is made (Table 1).

The logical schema is presented below:

\begin{tabular}{|c|c|}
\hline Field Name & Attribute Description \\
\hline \multicolumn{2}{|r|}{ Borehole Entity } \\
\hline Bh_Id & Borehole Identification \\
\hline Bh_owner & Borehole owner \\
\hline Bh_loc & Borehole location \\
\hline Bh_depth & The depth of water below the surface \\
\hline Bh_cond & The condition of the borehole whether functioning or not \\
\hline \multicolumn{2}{|r|}{ Building Entity } \\
\hline B_ld & Building Identification \\
\hline B_use & The use of which Building is put \\
\hline Rd_Id & Road Identifier \\
\hline Bh_ld & Borehole Identifier \\
\hline W_Id & Hand dug well Identifier \\
\hline \multicolumn{2}{|r|}{ Road Entity } \\
\hline Rd_id & Road Identifier \\
\hline Rd_Nam & Road name \\
\hline Rd_status & Whether the Road is tarred or untarred \\
\hline \multicolumn{2}{|r|}{ River Entity } \\
\hline Rv_Id & River Identification \\
\hline Rv_Nam & River name \\
\hline \multicolumn{2}{|r|}{ Hand dug well Entity } \\
\hline W_Id & Hand dug well Identifier \\
\hline W_owner & Hand dug well owner \\
\hline W_Loc & Hand dug well location \\
\hline W_depth & Depth of the well \\
\hline
\end{tabular}




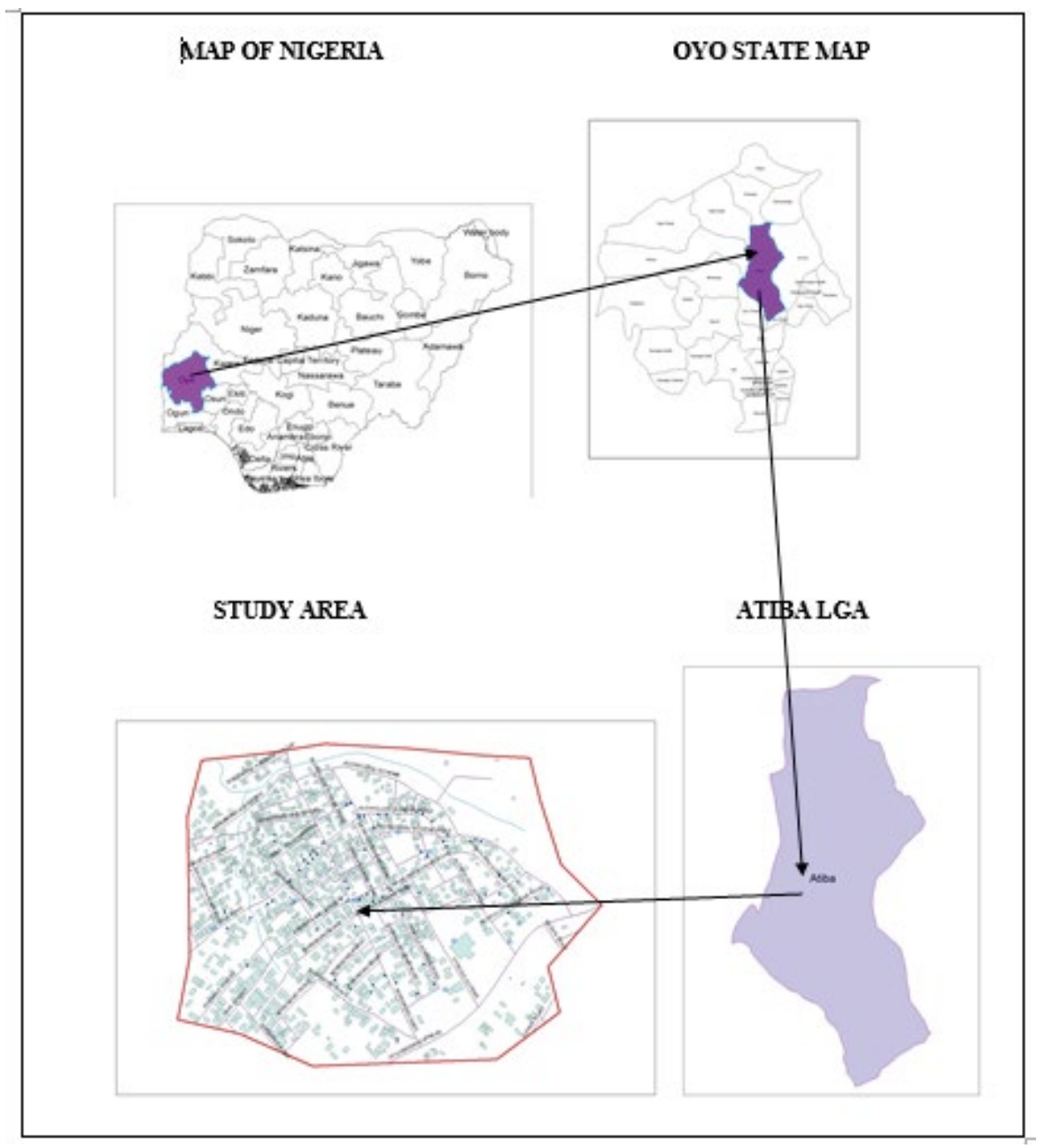

Figure 1: Map of the study area.

- Borehole Entity; Bh_Id, Bh_loc, Bh_owner, Bh_depth, Bh_cond

- Building Entity; B_Id, B_use,

- Road Entity; Rd_Id, Rd_name, Rd_status

- Hand Dug Well Entity; W_Id, W_Owner, W_depth, W_loc

\section{Physical design}

The physical design phase requires additional detail to describe how to model the spatial entities, their associated attributes and relationship between these entities. The internal storage structure and file organization of the database is specified during this phase. This is stage of database where data source is presented in the language of implementation.

The attribute data generated and logical design phase are actualized in the format of implementation software. For the purpose of this work, ARCGIS 10.3 is employed as the implementation software (Table 2).

\section{Database creation}

The database creation is executed in ARCGIS 10.3. Five tables are created for the hand dug wells, boreholes, buildings, roads and river in the study area. The data of each feature is entered into the tables for queries and other analyses to be carried out as will be show in the next chapter (Tables 3-7).

\section{Spatial Analyses and Product Generation \\ Spatial analysis}

This is the use of spatial and non-spatial data in GIS database to answer some generic questions like querying, buffering, classification and other GIS analysis about the real world by modeling. The model may reveal new or previously unidentified relationships within and between datasets, therefore increasing of our understanding of the real world (ESRI 1990).

The GIS analyses adopted in the real world are:

- Buffering operation,

- $\quad$ Retrieval (spatial query).

This GIS analyses will be performed considering the following criteria.

Criteria for the spatial allocation of hand dug well and borehole: This study only looks at the performance of the existing well in the study area and their distribution; and not site selection study but the 
Citation: Awodumi OE, Akeasa OS (2017) GIS Applications for Assessing Spatial Distribution of Boreholes and Hand Dug Wells in Boroboro Community, Atiba Local Government, Oyo State. J Remote Sensing \& GIS 6: 208. doi: 10.4172/2469-4134.1000208

Page 4 of 17

\begin{tabular}{|c|c|c|c|c|}
\hline Field & Attribute & Attribute Description & Data Type & Width \\
\hline \multirow{5}{*}{ BOREHOLE } & Bh_ld & Borehole identifier & Integer & 0 \\
\hline & Bh_owner & Borehole owner & Text & 30 \\
\hline & Bh_loc & Borehole location & Text & 30 \\
\hline & Bh_depth & The depth of water below the surface & Integer & 15 \\
\hline & Bh_status & The status of the borehole whether it is case or not & Text & 15 \\
\hline \multirow{5}{*}{ BUILDING } & B_Id & Building identifier & Integer & 0 \\
\hline & B_use & The use to which the building is put & Text & 30 \\
\hline & R_Id & Road identifier & Integer & 10 \\
\hline & Bh_ld & Borehole identifier & Integer & 10 \\
\hline & W_Id & Hand dug well identifier & Numeric & 0 \\
\hline \multirow{4}{*}{ HAND DUG WELL } & W_Id & Hand dug well Identifier & Numeric & 0 \\
\hline & W_owner & The owner of the hand dug well & Text & 30 \\
\hline & W_loc & The location of the hand dug well & Text & 30 \\
\hline & W_depth & Depth of the hand dug well & integer & 10 \\
\hline \multirow{4}{*}{ ROAD } & Rd_Id & Road Identifier & integer & 0 \\
\hline & Rd_owner & The owner of the road & Text & 30 \\
\hline & Rd_status & Whether the road is tarred or untarred & Text & 30 \\
\hline & Rd_name & The road name & & \\
\hline
\end{tabular}

Table 2: Data declaration of Entities and their Attributes.

\begin{tabular}{|c|c|c|c|c|c|c|c|c|}
\hline Object ID* & Shape* & Easting & Northing & W_location & W_ID & W_Owner & W_Depth & W_Condition \\
\hline 1 & Point & 605609.224 & 868786.107 & Alowolodu Scheme & 0 & Private & 18 & Functioning \\
\hline 2 & Point & 605633.245 & 868768.744 & Alowolodu Scheme & 0 & Private & 18 & Functioning \\
\hline 3 & Point & 605434.205 & 868876.383 & Oyekola Scheme & 0 & Private & 18 & Functioning \\
\hline 4 & Point & 605595.388 & 868255.187 & Oyekola Scheme & 0 & Private & 18 & Functioning \\
\hline 5 & Point & 605660.211 & 868290.906 & Oyekola Scheme & 0 & Private & 18 & Functioning \\
\hline 6 & Point & 605475.002 & 868321.333 & Boroboro & 0 & Private & 18 & Functioning \\
\hline 7 & Point & 605430.684 & 868284.952 & Boroboro & 0 & Private & 18 & Functioning \\
\hline 8 & Point & 605424.07 & 868259.156 & Boroboro & 0 & Private & 18 & Functioning \\
\hline 9 & Point & 605347.34 & 868273.046 & Boroboro & 0 & Private & 18 & Not Functioning \\
\hline 10 & Point & 605288.493 & 868305.061 & Boroboro & 0 & Private & 18 & Functioning \\
\hline 11 & Point & 605376.658 & 868922.686 & Alowolodu Scheme & 0 & Private & 18 & Functioning \\
\hline 12 & Point & 605380.627 & 868912.764 & Alowolodu Scheme & 0 & Private & 18 & Functioning \\
\hline 13 & Point & 605397.825 & 868918.717 & Oyekola Scheme & 0 & Private & 18 & Functioning \\
\hline 14 & Point & 605517.335 & 868294.213 & Boroboro & 0 & Private & 18 & Functioning \\
\hline 15 & Point & 605346.893 & 868969.649 & Alowolodu Scheme & 0 & Public & 18 & Functioning \\
\hline 16 & Point & 605331.749 & 868961.402 & Alowolodu Scheme & 0 & Private & 10 & Functioning \\
\hline 17 & Point & 605450.742 & 868924.67 & Alowolodu Scheme & 0 & Private & 10 & Functioning \\
\hline 18 & Point & 605480.448 & 868924.055 & Alowolodu Scheme & 0 & Private & 10 & Functioning \\
\hline 19 & Point & 605595.411 & 868934.77 & Alowolodu Scheme & 0 & Private & 10 & Functioning \\
\hline 20 & Point & 605616.577 & 868926.833 & Alowolodu Scheme & 0 & Private & 18 & Functioning \\
\hline 21 & Point & 605653.619 & 868900.375 & Alowolodu Scheme & 0 & Private & 18 & Functioning \\
\hline 22 & Point & 605711.828 & 868847.458 & Alowolodu Scheme & 0 & Private & 10 & Functioning \\
\hline 23 & Point & 605693.307 & 868826.291 & Alowolodu Scheme & 0 & Private & 10 & Functioning \\
\hline 24 & Point & 605706.536 & 868805.124 & Alowolodu Scheme & 0 & Private & 18 & Functioning \\
\hline 25 & Point & 605812.016 & 868830.524 & Alowolodu Scheme & 0 & Private & 18 & Functioning \\
\hline
\end{tabular}

Table 3: Sample of Populated Table for Wells.

rules must also be followed to guide us in carrying out the intended analyses. The following guideline must be considered when allocating site for hand dug wells and boreholes in an environment. They are enumerated below:

a. The walking distance from a well in an urban setting must not be more than $200 \mathrm{~m}$,

b. The hand dug well must deeper than $60 \mathrm{ft}$ (18 meter) and boreholes depth around the study area must be deeper than $50 \mathrm{~m}$.

The hand dug well must be covered and the borehole must be cased down and covered to avoid been contaminated by infiltration by run-off and contaminated from the surface (Figure 2).

\section{Cartographic modeling}

This is a graphical representation of data and the analytical procedures used for the study. It involves step-by-step of the way the project was carrying out (Figure 3).

\section{Spatial query}

Spatial criterion query, single criterion: Syntax: Select* from "W owner"=Private" (Figures 4-6)

Query 2

Syntax: Select* from "BH_owner"='Public' (Figures 7-9) 
Citation: Awodumi OE, Akeasa OS (2017) GIS Applications for Assessing Spatial Distribution of Boreholes and Hand Dug Wells in Boroboro Community, Atiba Local Government, Oyo State. J Remote Sensing \& GIS 6: 208. doi: 10.4172/2469-4134.1000208

Page 5 of 17

\begin{tabular}{|c|c|c|c|c|c|c|c|c|}
\hline Object ID* & Shape* & Easting & Northing & BH_location & BH_Depth & BH_Owner & BH_ID & BH_Condition \\
\hline 2 & Point & 605523.826 & 868863.903 & Alowolodu Scheme & 45 & Private & 1 & Functioning \\
\hline 3 & Point & 605640.317 & 868786.406 & Alowolodu Scheme & 50 & Private & 2 & Functioning \\
\hline 4 & Point & 605140.958 & 868603.578 & Oyekola Scheme & 50 & Public & 3 & Functioning \\
\hline 5 & Point & 605131.402 & 868594.757 & Oyekola Scheme & 50 & Private & 4 & Functioning \\
\hline 6 & Point & 604840.437 & 868496.453 & Isale Yidi Agunpopo & 45 & Private & 5 & Functioning \\
\hline 7 & Point & 605700.642 & 868269.938 & Oyekola Scheme & 50 & Private & 6 & Functioning \\
\hline 8 & Point & 605940.545 & 868450.491 & Alowolodu Scheme & 50 & Private & 7 & Functioning \\
\hline 9 & Point & 605976.925 & 868516.637 & Alowolodu Scheme & 50 & Private & 8 & Functioning \\
\hline 11 & Point & 605361.975 & 868603.578 & Oyekola Scheme & 45 & Private & 9 & Functioning \\
\hline 12 & Point & 605728.878 & 868450.491 & Atiba Local Govt & 50 & Public & 10 & Functioning \\
\hline
\end{tabular}

Table 4: Sample of Populated Table for Borehole.

\begin{tabular}{|c|c|c|c|}
\hline Object ID $^{*}$ & Shape $^{*}$ & Shape_Length & STRM_Name \\
\hline 1 & Polyline & 1017.48458 & Ashipa \\
\hline 2 & Polyline & 1142.85685 & Ahoyaya Rive \\
\hline
\end{tabular}

Table 5: Sample of Populated Table for River.

\begin{tabular}{|c|c|c|c|c|c|}
\hline $\begin{array}{l}\text { Object } \\
\text { ID* }\end{array}$ & Shape* & $\begin{array}{l}\text { Shape } \\
\text { Length }\end{array}$ & RD_Name & $\begin{array}{l}\text { RD_ } \\
\text { Lane }\end{array}$ & RD_Status \\
\hline 1 & Polyline & 1218.36878 & $\begin{array}{l}\text { Oyo-Ibadan- } \\
\text { Express }\end{array}$ & 0 & Tarred \\
\hline 2 & Polyline & 1156.91987 & Boroboro-Sabo & 0 & Tarred \\
\hline 3 & Polyline & 837.938822 & Oyekola Scheme & 5 & Untarred \\
\hline 4 & Polyline & 628.780753 & Alowolodu Scheme & 6 & Untarred \\
\hline 5 & Polyline & 689.705466 & Alowolodu Scheme & 8 & Untarred \\
\hline 6 & Polyline & 636.311987 & $\begin{array}{l}\text { Boroboro- } \\
\text { Agunpopo }\end{array}$ & 0 & Untarred \\
\hline 7 & Polyline & 609.737302 & $\begin{array}{l}\text { Boroboro- } \\
\text { Agunpopo }\end{array}$ & 0 & Untarred \\
\hline 8 & Polyline & 1008.22208 & Tola Road & 0 & Tarred \\
\hline 9 & Polyline & 441.067912 & Tafa Street & 0 & Untarred \\
\hline 10 & Polyline & 559.406313 & Boroboro Road & 0 & Untarred \\
\hline 11 & Polyline & 545.4926 & Boroboro Road & 0 & Untarred \\
\hline 12 & Polyline & 428.160914 & Boroboro Road & 0 & Untarred \\
\hline 13 & Polyline & 334.756733 & Ajegunle Road & 0 & Tarred \\
\hline 14 & Polyline & 504.406563 & Adewale Street & 0 & Untarred \\
\hline 15 & Polyline & 401.369886 & Isale Yidi Road & 0 & Tarred \\
\hline 16 & Polyline & 213.816722 & Oyekola Scheme & 3 & Untarred \\
\hline 17 & Polyline & 160.363145 & Oyekola Scheme & 1 & Untarred \\
\hline 18 & Polyline & 298.175518 & Oyekola Scheme & 5 & Untarred \\
\hline 19 & Polyline & 375.895462 & Oyekola Scheme & 2 & Untarred \\
\hline 20 & Polyline & 149.275976 & Oyekola Scheme & 2 & Untarred \\
\hline 21 & Polyline & 330477816 & Oyekola Scheme & 4 & Untarred \\
\hline 22 & Polyline & 146.996831 & Oyekola Scheme & 4 & Untarred \\
\hline
\end{tabular}

Table 6: Sample of Populated Table for Road.

Multiple Criteria. Query 3

Syntax: Select ${ }^{*}$ from W_Owner='PRIVATE' And W_ Condition='Not Functioning' (Figures 10-12).

\section{Buffering operation}

This is a spatial function in which area/zone of interest is created around the given features or object. These analyses are done to see the buildings that are falls within the set criteria of $200 \mathrm{~m}$ radius of each of the borehole and wells. It is performed by creating the $200 \mathrm{~m}$ buffer round the hand dug wells and boreholes and at the same time intersecting the buffered zones around these selected hands dug wells and boreholes (Figures 13-19) respectively.

Then the walking distance to the hand dug wells and boreholes are determined with respect to the building that did not fall within the buffer zones. The first $200 \mathrm{~m}$ buffering was performed on the nine boreholes to know areas that lack access to borehole water in the study area (Borehole) as shown in Figure 13.

Figure 14 shows areas cover by the $200 \mathrm{~m}$ coverage of the existing nine boreholes in the study area. This indicates that large area of Boroboro community lack access to both private and public boreholes in the community. Areas such as Adewale, Tafa and Ajegunle in the south west of the community lack access to borehole water. In the north east of the community, areas such as Boroboro-Agunpopo and Boroboroisale yidi down to alowolodu in the north lack access to potable water and other areas. Other areas lack access to boreholes water are Oyekola, areas along oyo - Ibadan expressway, Estate and Ahoyaya.

Figures 16 shows virtually all areas in the community possesses hand dug well, however, some areas especially the developing areas such as Adewale, Tafa, Boroboro- agunpopo and Estate lacks hand dug well and borehole and almost lack access to well water in the study area. A sample survey of two hand dug wells (well 13 and 57) in Figures 17 and 18 below shows the extends of coverage, the number of houses covers, the estimated population serves, this was calculated by number of building divided by household standard and the number of street covers (Table 8).

\section{Overlay operation}

Union: Another important spatial operation performed is Union. This computes a geometric union of the input feature class. The buffering of the boreholes and hand-dug wells were overlaid to be able to know those who have access to both the boreholes and the hand dug well. The result showed that 607 buildings depend on the boreholes and the hand dug wells for their water needs. On the other hand, 127 buildings according to the set criteria of $200 \mathrm{~m}$ waking distance have no access to the facilities. The result is shown in Figures 20 and 21.

\section{Discussion of result}

Buffer operation was employed to determine localities that hand dug wells and boreholes served. There was a clear indication that Alowolodu, Femi Fajobi, Tola, Boroboro and oyekola area all in the 
Citation: Awodumi OE, Akeasa OS (2017) GIS Applications for Assessing Spatial Distribution of Boreholes and Hand Dug Wells in Boroboro Community, Atiba Local Government, Oyo State. J Remote Sensing \& GIS 6: 208. doi: 10.4172/2469-4134.1000208

Page 6 of 17

\begin{tabular}{|c|c|c|c|c|c|}
\hline Objected & Shape & Shape_Length & Shape_Area & B_Location & B_Use \\
\hline 122 & Polygon & 62.542857 & 228.727678 & Alowolodu Schem & Residential \\
\hline 123 & Polygon & 87.544569 & 389.003417 & Alowolodu Schem & Residential \\
\hline 124 & Polygon & 63.788898 & 245.299462 & Alowolodu Schem & Residential \\
\hline 125 & Polygon & 60.772469 & 222.370475 & Alowolodu Schem & Residential \\
\hline 126 & Polygon & 58.250508 & 188.600774 & Alowolodu Schem & Residential \\
\hline 127 & Polygon & 49.063967 & 143.140015 & Alowolodu Schem & Residential \\
\hline 128 & Polygon & 48.741243 & 145.502614 & Alowolodu Schem & Residential \\
\hline 129 & Polygon & 69.550168 & 266.74854 & Alowolodu Schem & Residential \\
\hline 130 & Polygon & 49.024458 & 147.957019 & Alowolodu Schem & Residential \\
\hline 131 & Polygon & 52.545141 & 170.59741 & Alowolodu Schem & Residential \\
\hline 132 & Polygon & 56.837659 & 185.582961 & Alowolodu Schem & Residential \\
\hline 133 & Polygon & 39.392709 & 96.534019 & Alowolodu Schem & Residential \\
\hline 134 & Polygon & 67.468267 & 243.759822 & Alowolodu Schem & Residential \\
\hline 135 & Polygon & 53.089886 & 169.986912 & Alowolodu Schem & Residential \\
\hline 136 & Polygon & 51.921825 & 168.461764 & Alowolodu Schem & Residential \\
\hline 137 & Polygon & 58.632311 & 203.159944 & Alowolodu Schem & Residential \\
\hline 138 & Polygon & 63.599386 & 237.493262 & Alowolodu Schem & Residential \\
\hline 139 & Polygon & 37.544344 & 82.37113 & Alowolodu Schem & Residential \\
\hline 140 & Polygon & 58.333119 & 208.253078 & Alowolodu Schem & Residential \\
\hline 141 & Polygon & 103.670526 & 470.01753 & Alowolodu Schem & Residential \\
\hline 142 & Polygon & 54.960772 & 188.44944 & Alowolodu Schem & Residential \\
\hline 143 & Polygon & 72.34906 & 325.245773 & Alowolodu Schem & Residential \\
\hline 144 & Polygon & 61.191689 & 226.853242 & Alowolodu Schem & Residential \\
\hline 145 & Polygon & 86.076885 & 396.518515 & Alowolodu Schem & Residential \\
\hline
\end{tabular}

Table 7: Sample of Populated Table for BUILDNG.

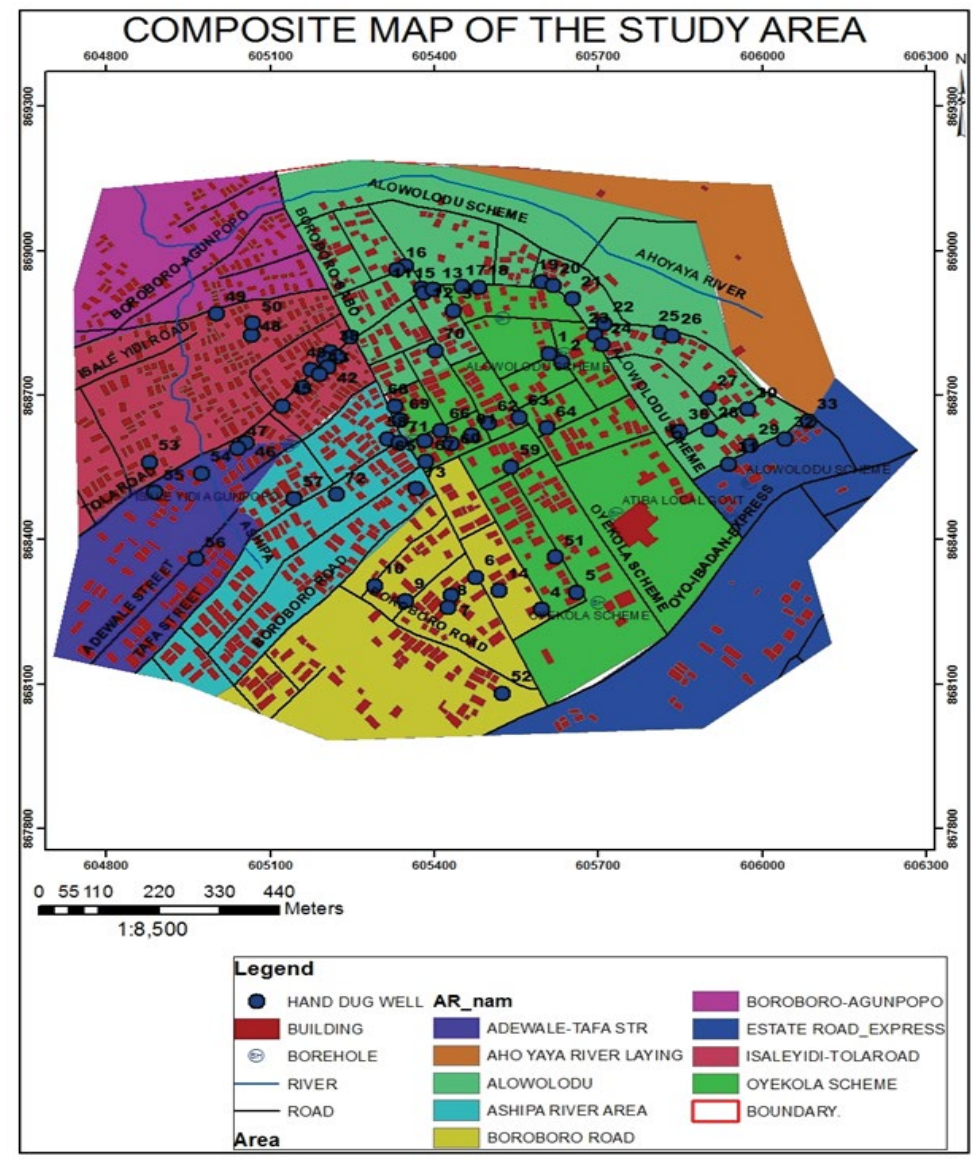

Figure 2: Composite map of the study area. 


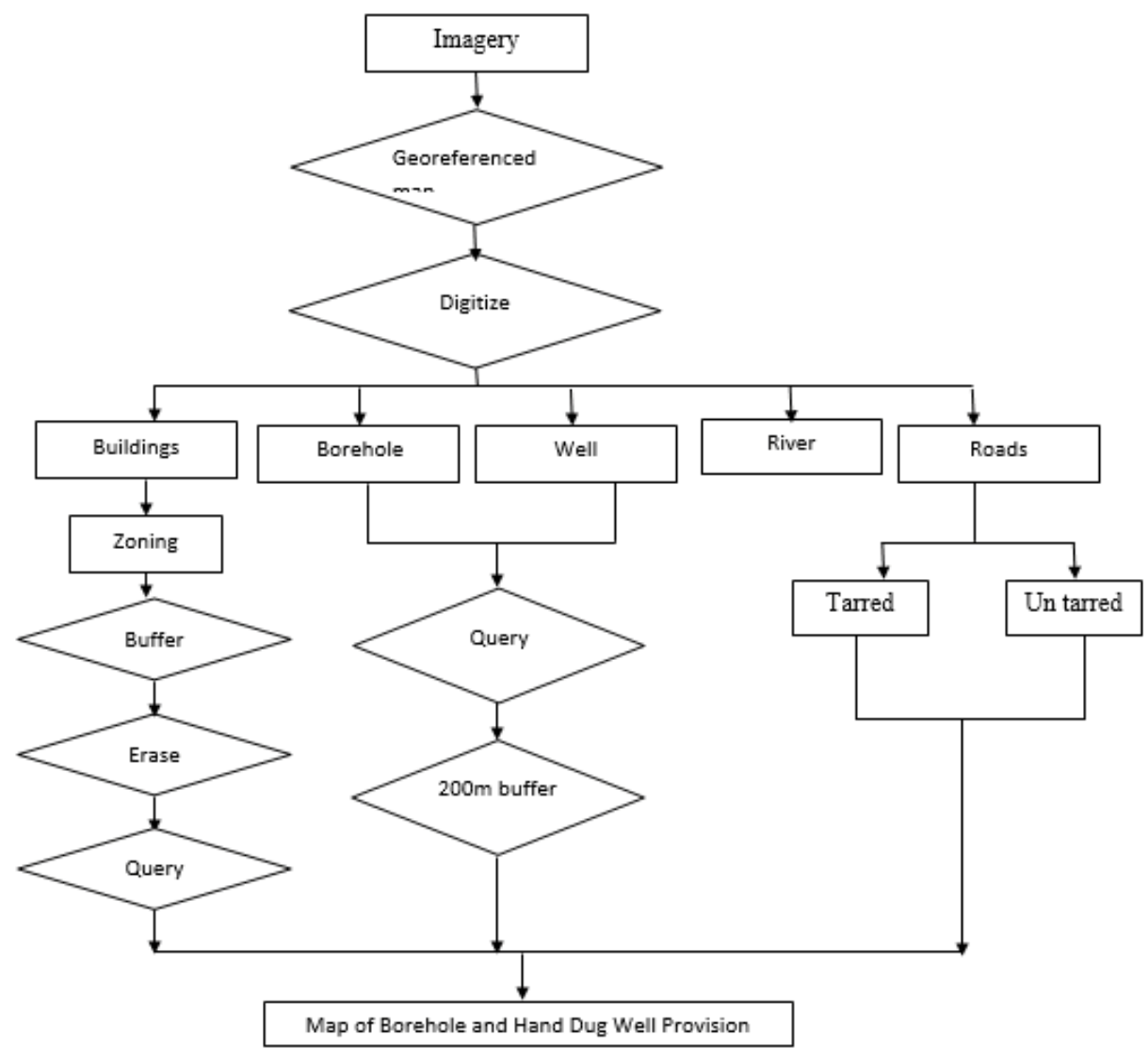

Figure 3: Cartographic Modelling

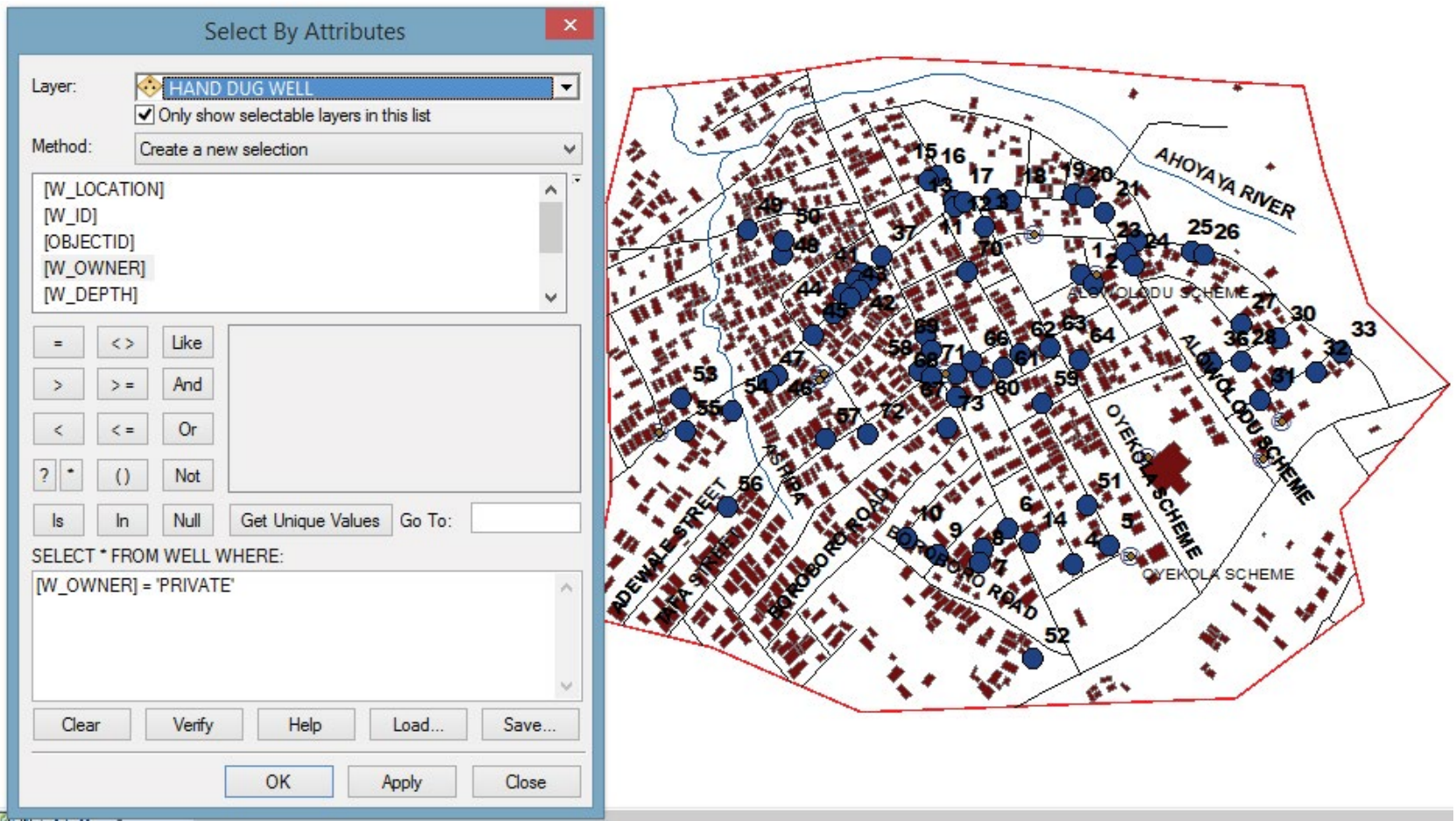

Figure 4: Query for wells that are private. 


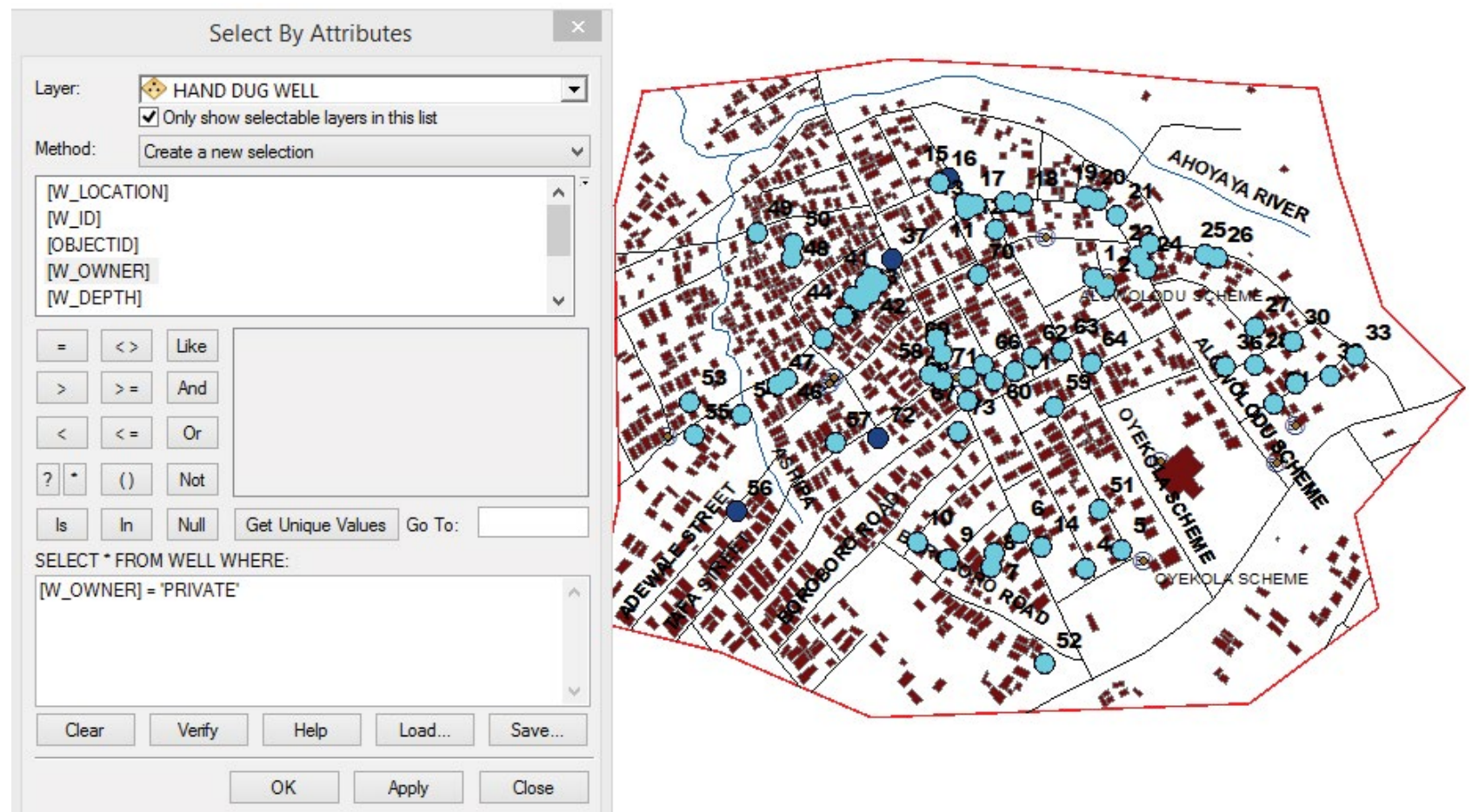

Figure 5: Result of Query of wells that are private.

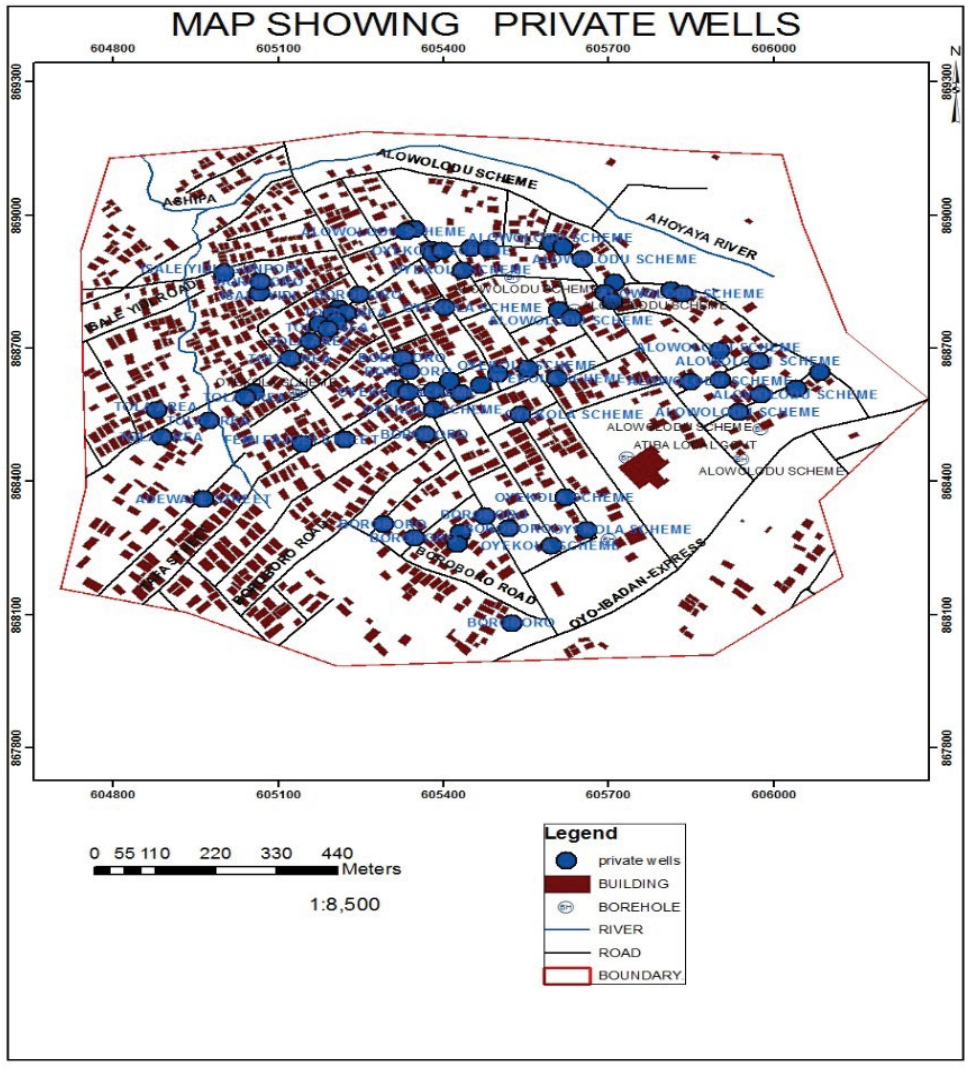

Figure 6: Map of private wells. 
Citation: Awodumi OE, Akeasa OS (2017) GIS Applications for Assessing Spatial Distribution of Boreholes and Hand Dug Wells in Boroboro Community, Atiba Local Government, Oyo State. J Remote Sensing \& GIS 6: 208. doi: 10.4172/2469-4134.1000208

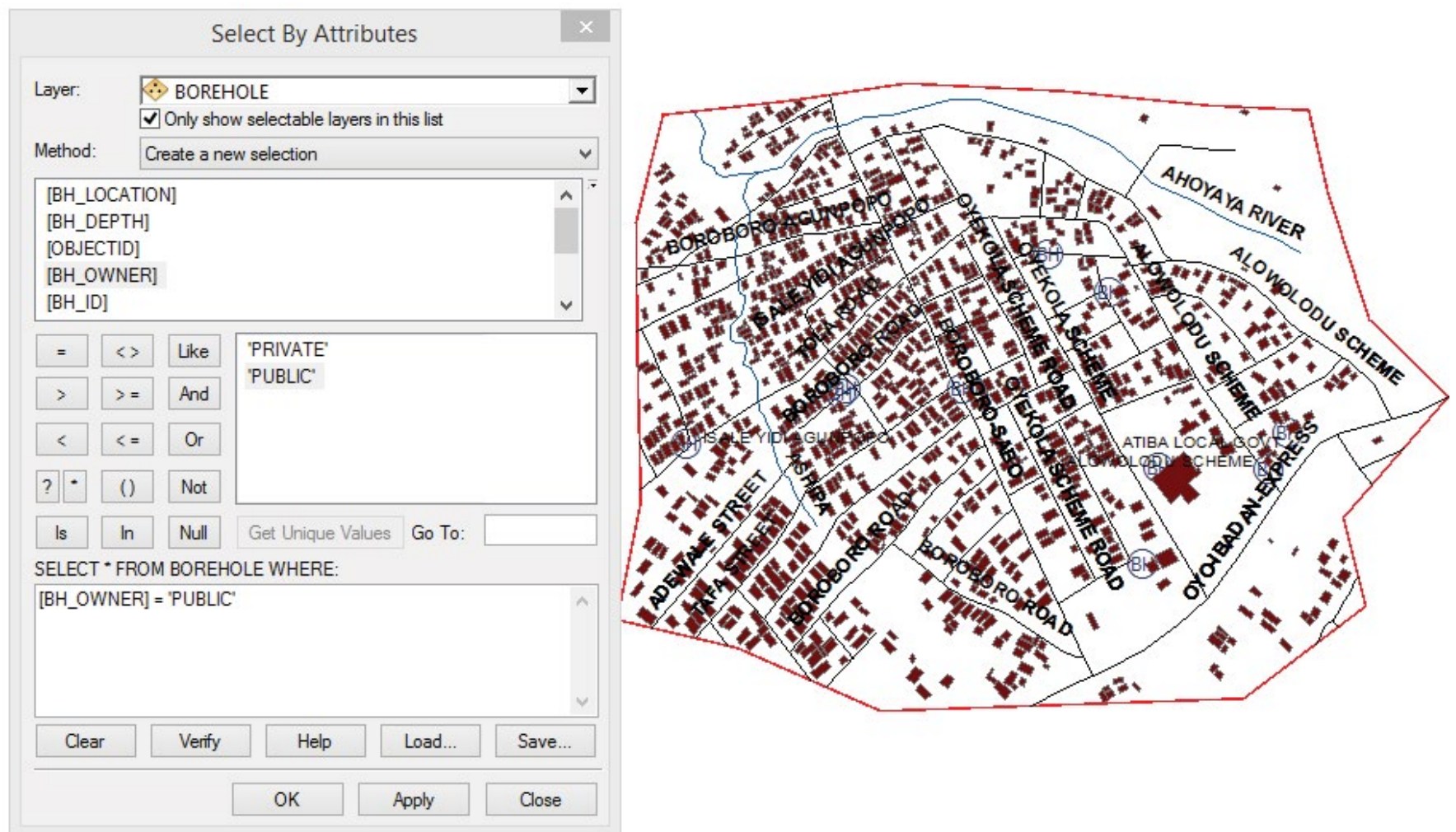

Figure 7: Query for borehole that are public.

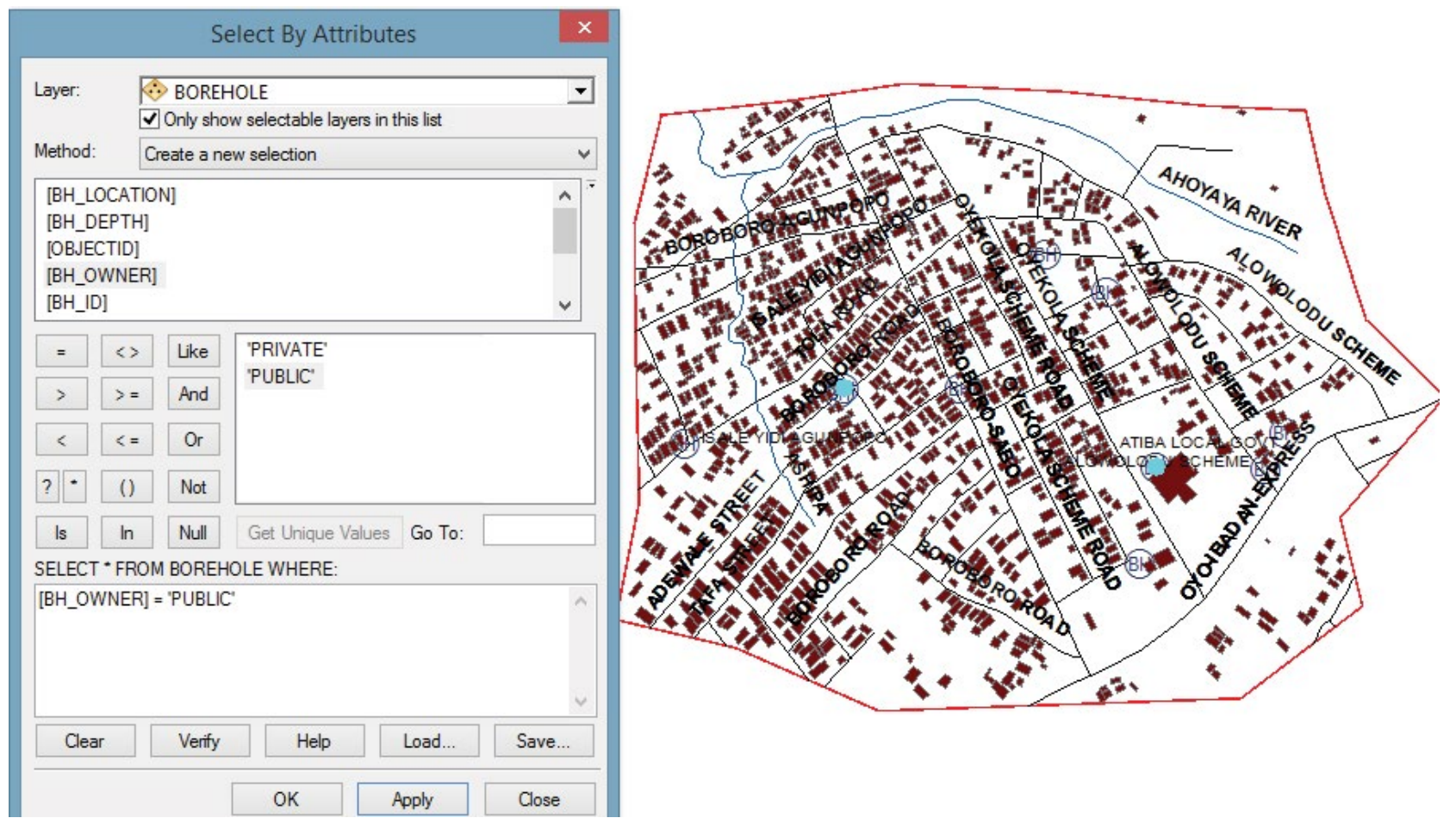

Figure 8: Result of Query of borehole that are public. 


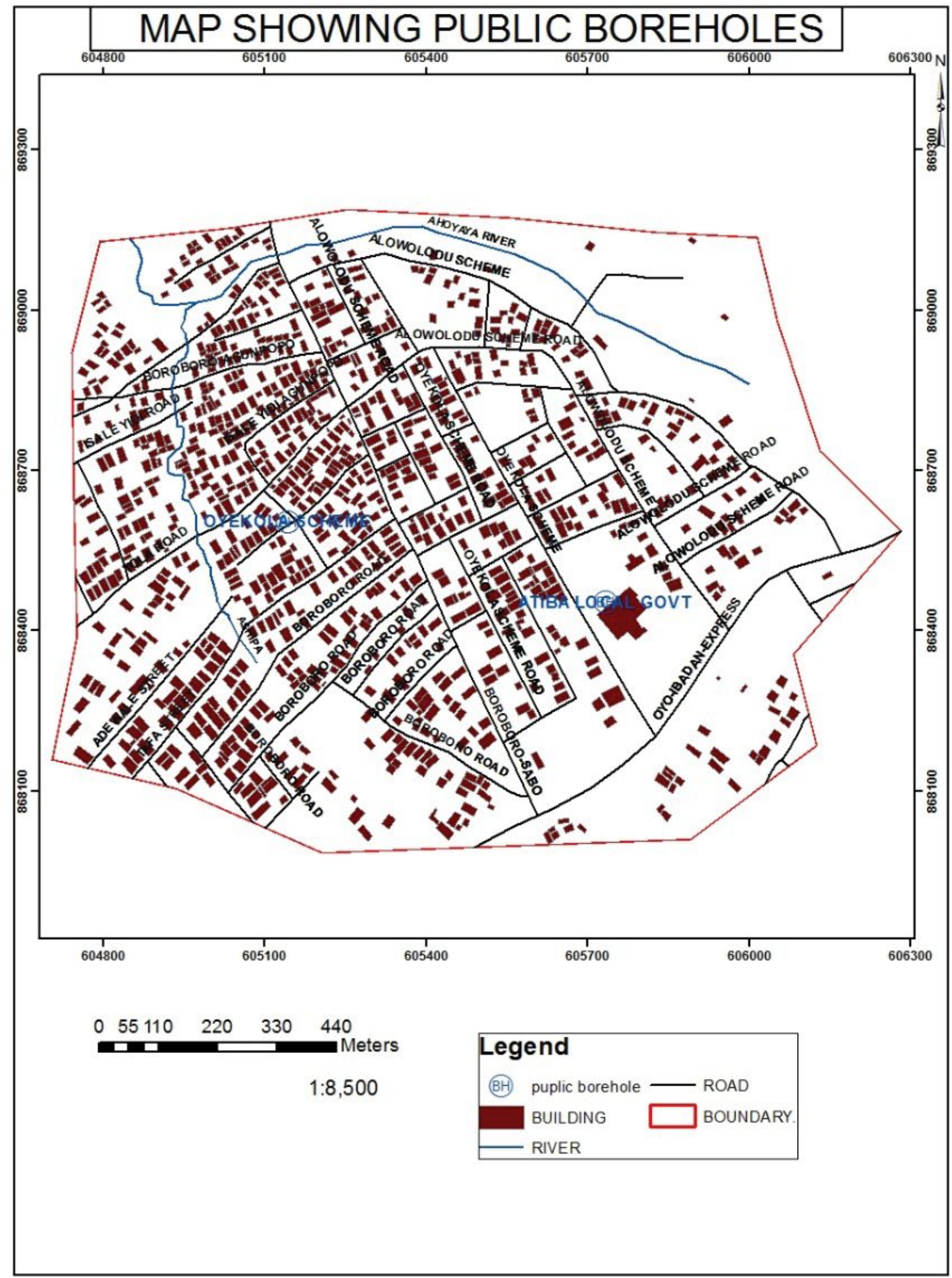

Figure 9: Map of public boreholes. 
Citation: Awodumi OE, Akeasa OS (2017) GIS Applications for Assessing Spatial Distribution of Boreholes and Hand Dug Wells in Boroboro Community, Atiba Local Government, Oyo State. J Remote Sensing \& GIS 6: 208. doi: 10.4172/2469-4134.1000208

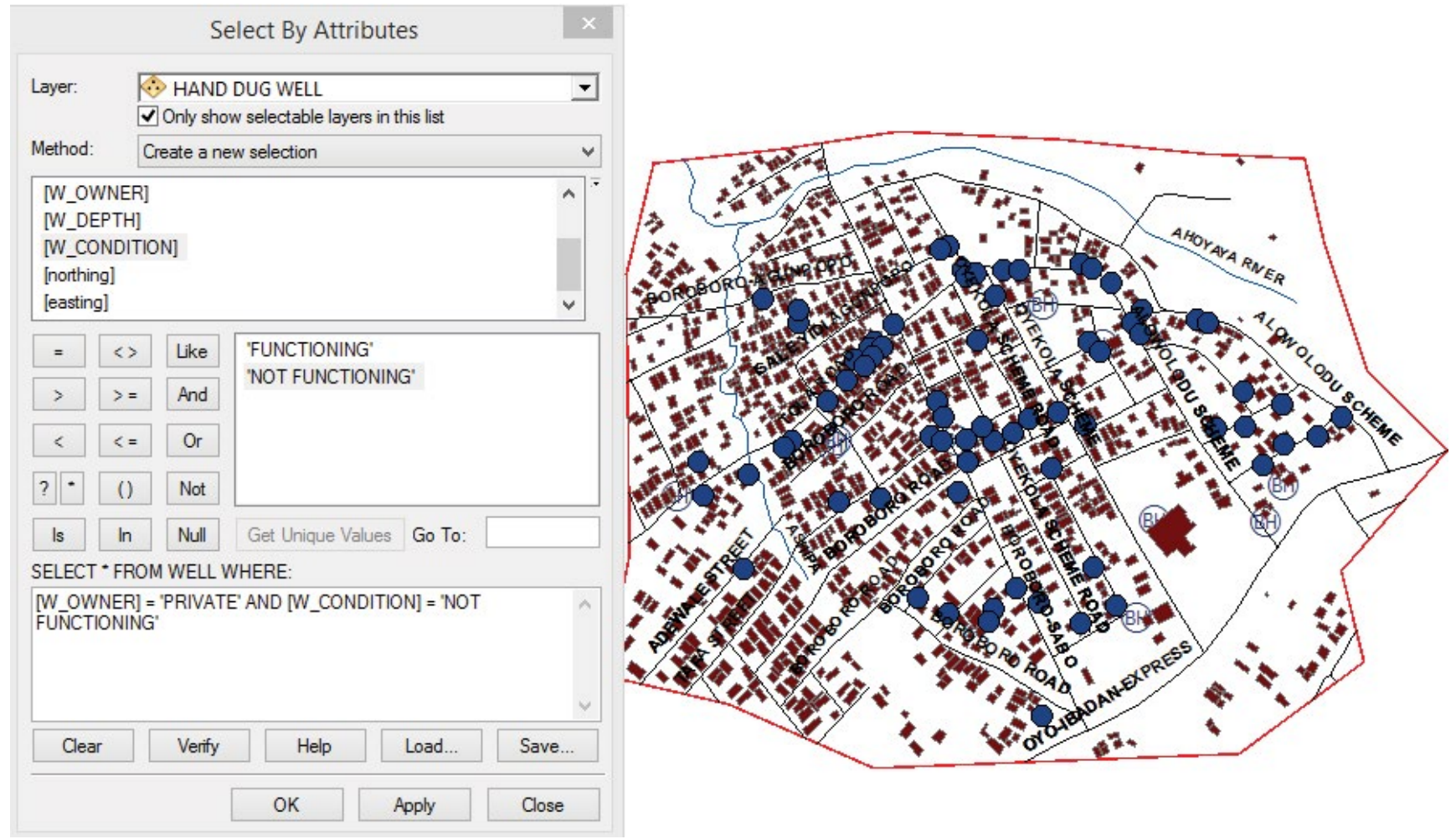

Figure 10: Query for private wells that are not functioning

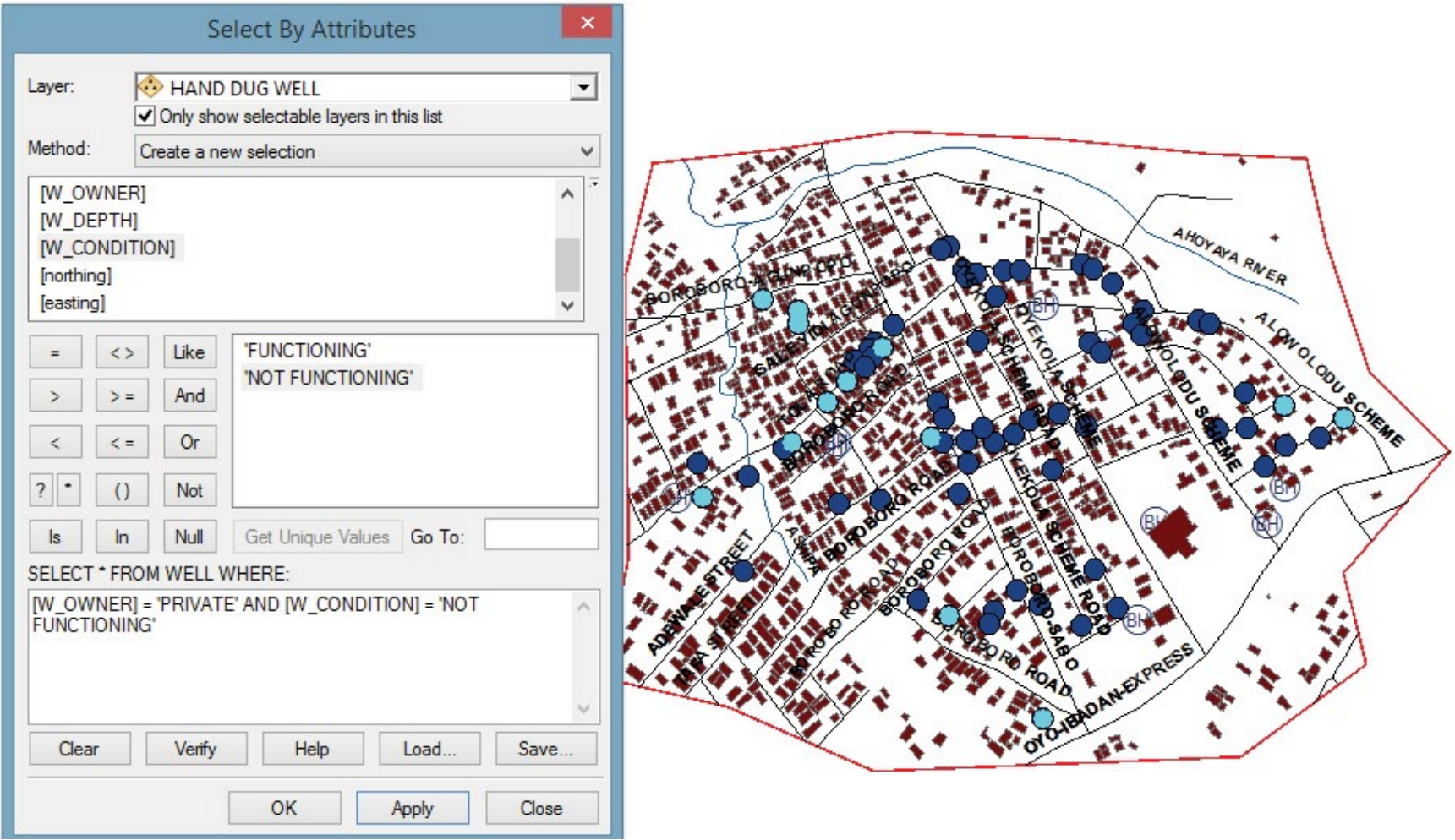

Figure 11: Result of query of private wells that are not functioning. 


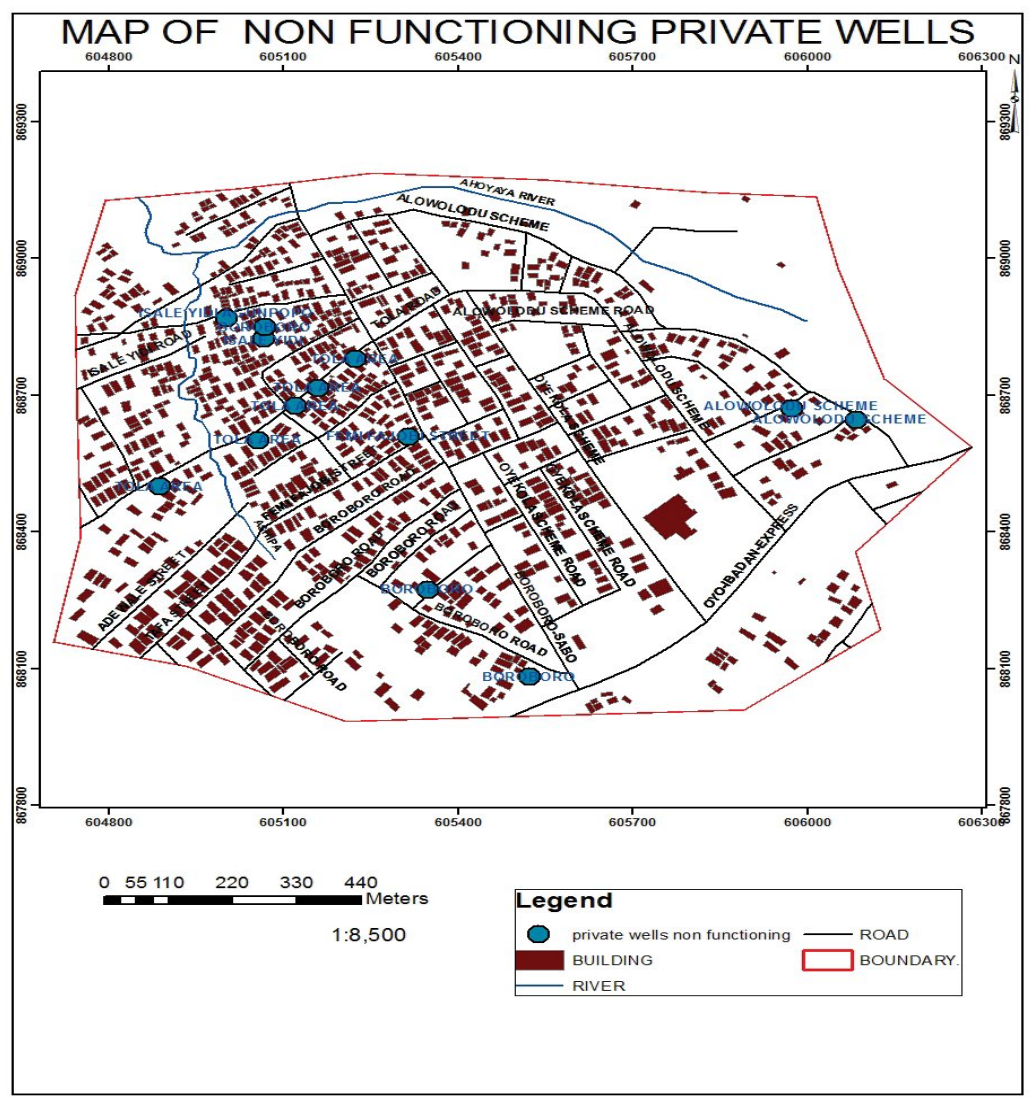

Figure 12: Map of non-functioning private wells.

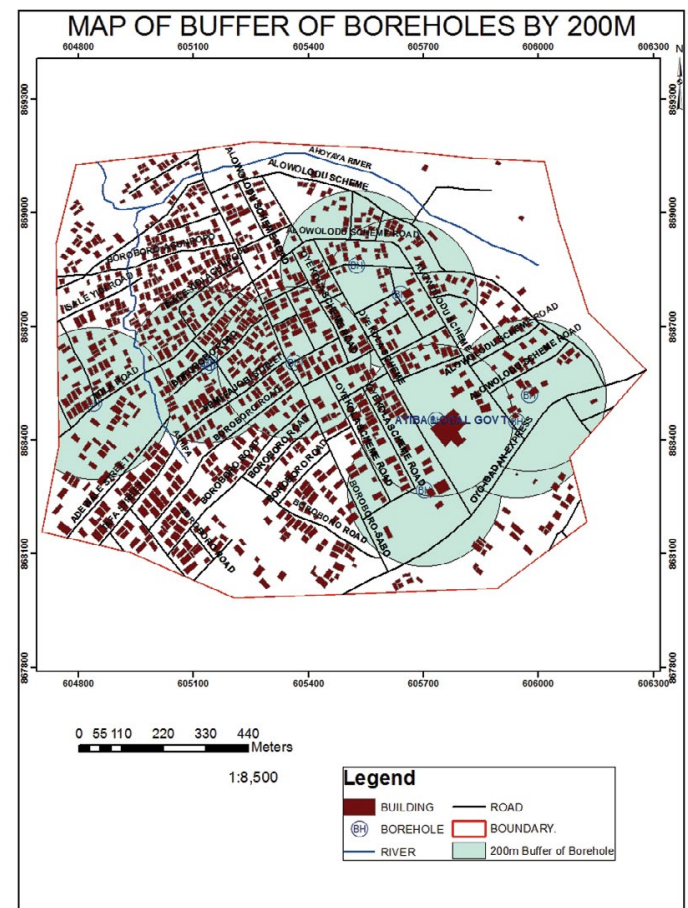

Figure 13: Map Of buffered boreholes by 200 meters. 
Citation: Awodumi OE, Akeasa OS (2017) GIS Applications for Assessing Spatial Distribution of Boreholes and Hand Dug Wells in Boroboro Community, Atiba Local Government, Oyo State. J Remote Sensing \& GIS 6: 208. doi: 10.4172/2469-4134.1000208

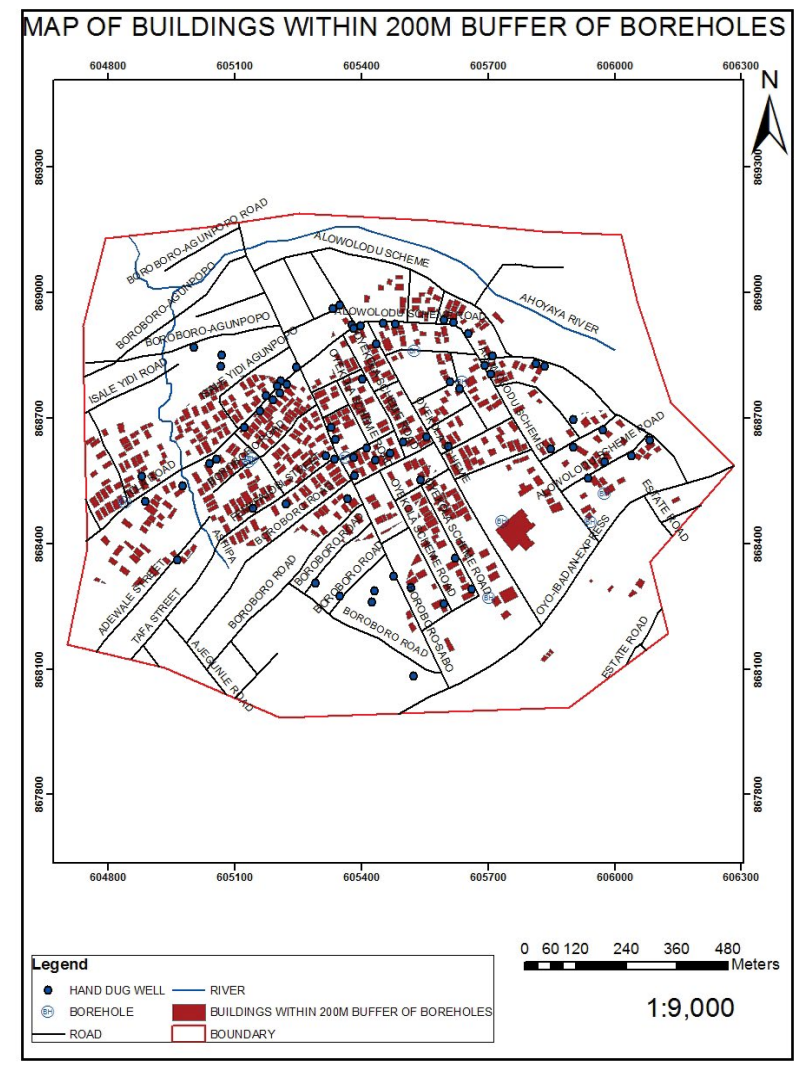

Figure 14: Map of buildings within $200 \mathrm{~m}$ buffer of boreholes.

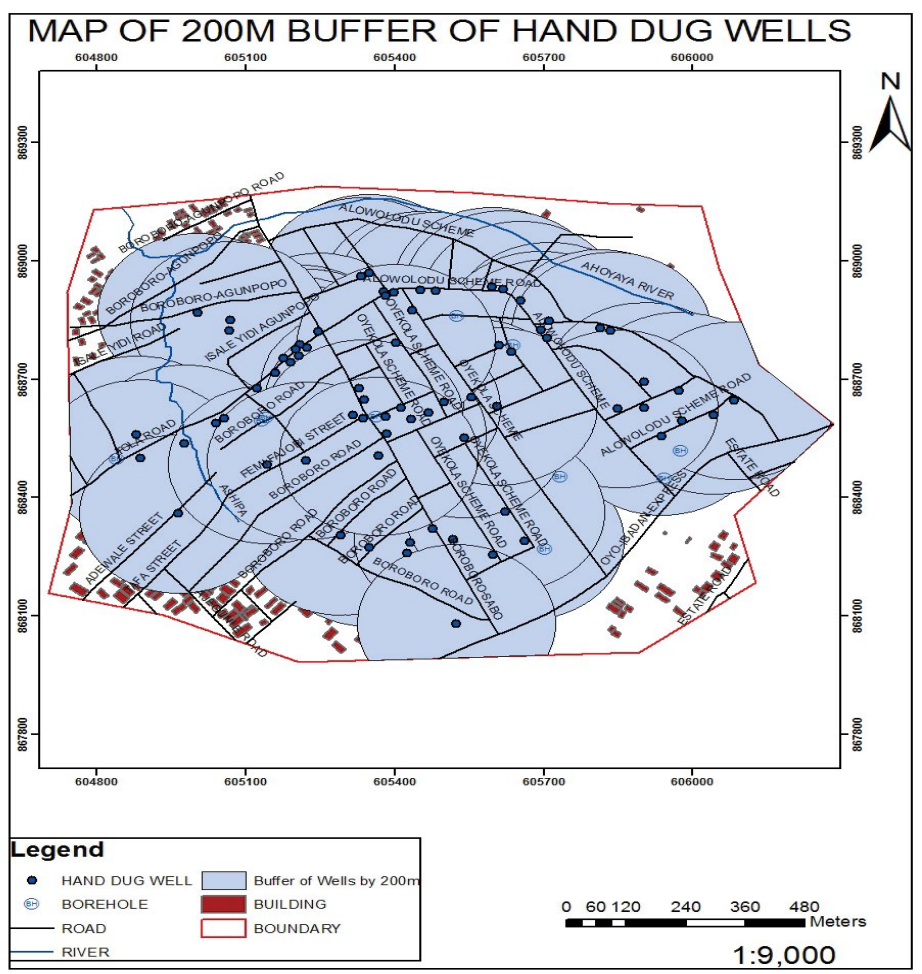

Figure 15: Map of $200 \mathrm{~m}$ Buffer of Hand dug Wells. 


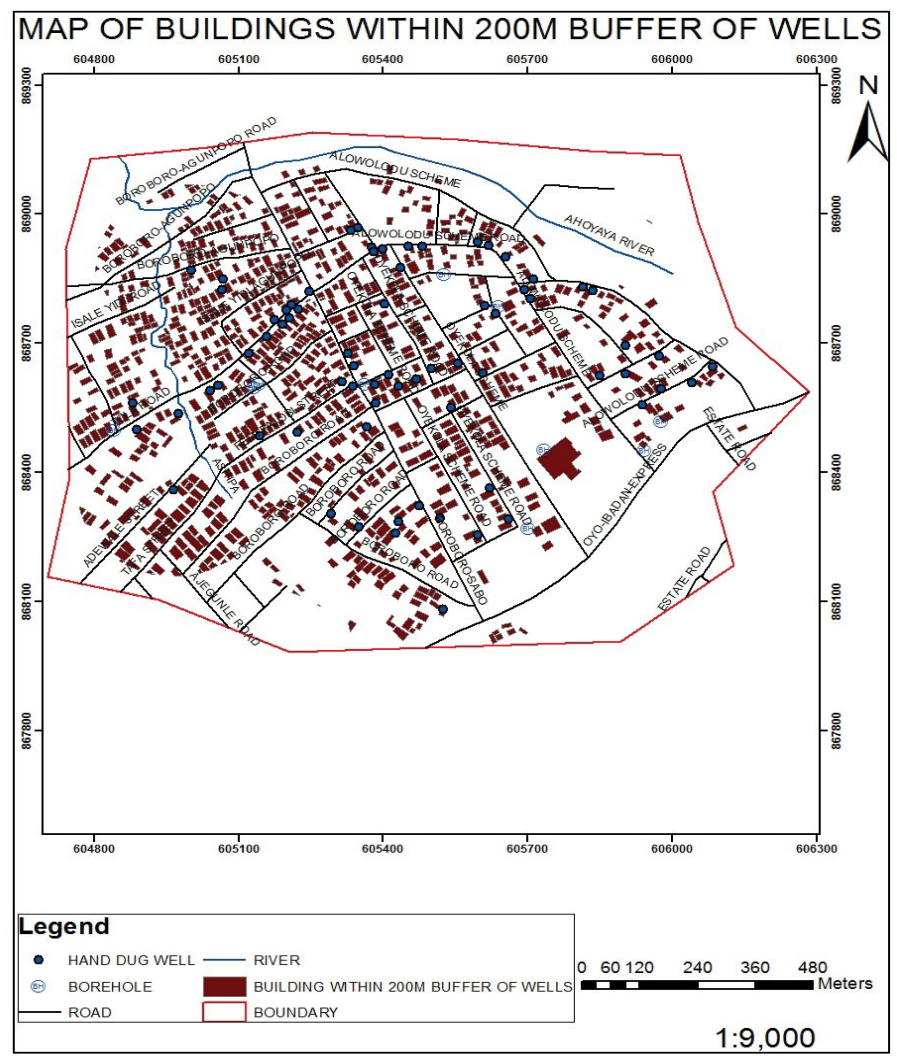

Figure 16: Map of $200 \mathrm{~m}$ Buffer of Hand dug Wells

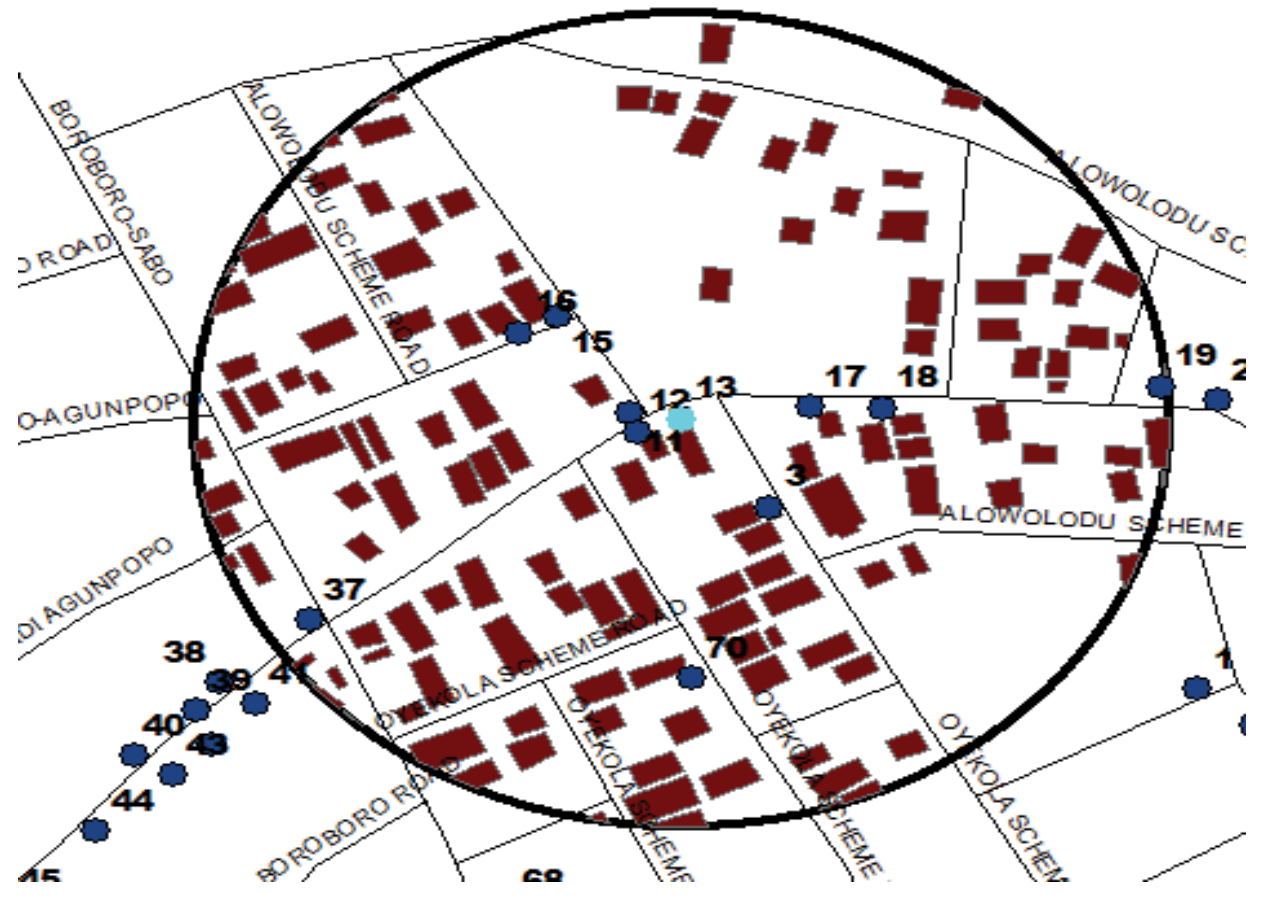

Figure 17: $200 \mathrm{~m}$ buffer of well 13. 


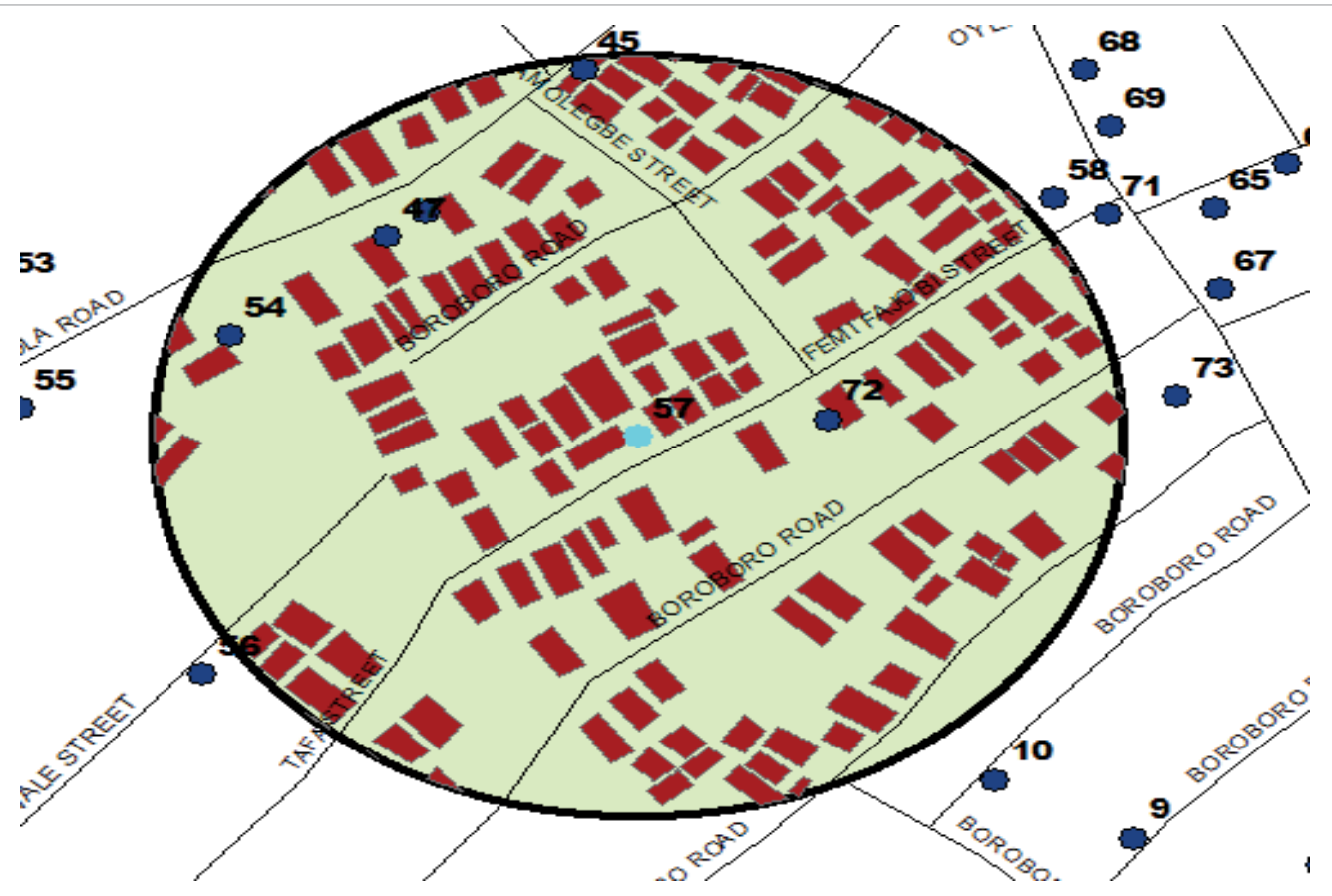

Figure 18: $200 \mathrm{~m}$ buffer of well 57.

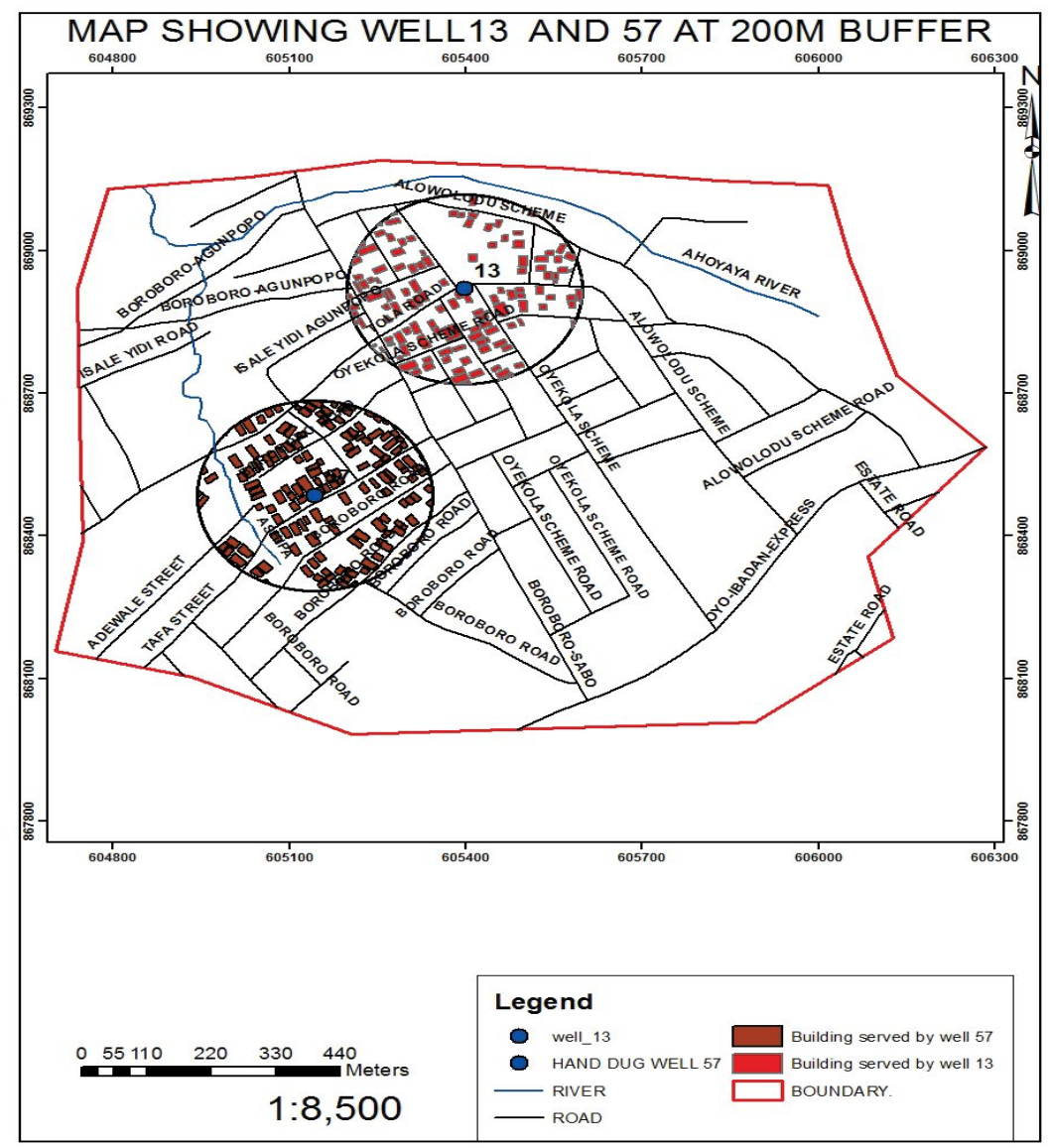

Figure 19: Map Showing Well 13 and 57 Buffer. 


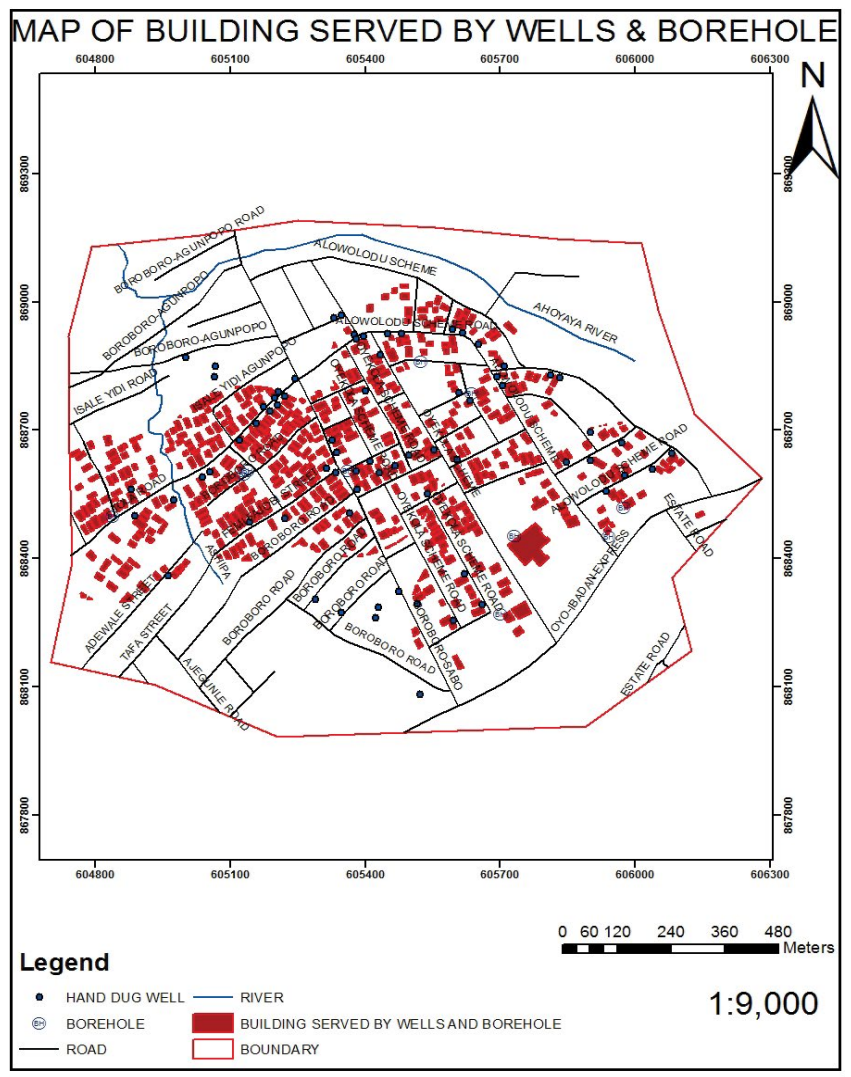

Figure 20: Map of buildings served by boreholes and wells.

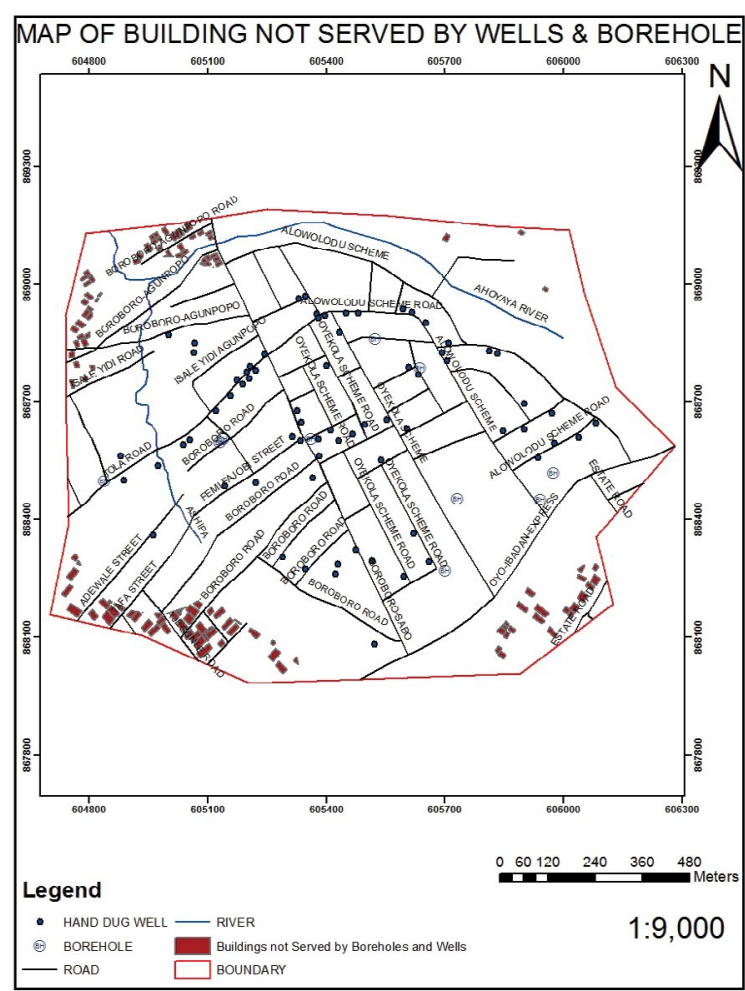

Figure 21: Map of Buildings Not Served by Boreholes and Wells. 
Citation: Awodumi OE, Akeasa OS (2017) GIS Applications for Assessing Spatial Distribution of Boreholes and Hand Dug Wells in Boroboro Community, Atiba Local Government, Oyo State. J Remote Sensing \& GIS 6: 208. doi: 10.4172/2469-4134.1000208

\begin{tabular}{|c|c|c|c|c|c|}
\hline Well & $\begin{array}{c}\text { No. of } \\
\text { Buildings } \\
\text { Served }\end{array}$ & $\begin{array}{c}\text { Estimated } \\
\text { Population }\end{array}$ & $\begin{array}{c}\text { Daily } \\
\text { Consumption/ } \\
\text { Person (Litre) }\end{array}$ & $\begin{array}{c}\text { Number of } \\
\text { Consumption/ } \\
\text { Day (M } \mathbf{M}^{3} \text { ) }\end{array}$ & Fig \\
\hline 13 & 134 & 804 & 230 & 184.92 & 13 \\
\hline 57 & 155 & 930 & 230 & 213.9 & 14 \\
\hline
\end{tabular}

Table 8: Buffer of well 13 and 57.

centre of the community have a clustering arrangement, possesses much amount of boreholes and hand dug wells thereby have large access to water supply in the study area while Isale-yidi Agunpopo, Ahoyaya, Estate and Adewale area have a low numbers of borehole and hand dug wells and have little or no access to water facilities. And these areas are extensions of Boroboro community that are just witnessing development.

This research also shows virtually all the boreholes in this community were in a good condition but owns by individual (private) only two are public and some hand dug wells are in a bad condition due to bad maintenance culture of the users. The analysis performed shosws out of 1701 buildings which has a total population of 8505 (number of buildings multiply by estimated Nigerian household standard) in the study area, only 603 buildings with total population of 3015 people have access to borehole water while 971 building with the population of 4855 people have access to hand dug well. Also, 607 building with the population of 3035 people have access to both boreholes and hand dug wells while 127 buildings with total population of 635 people could not access boreholes or hand dug wells.

\section{Summary, Conclusion and Recommendations}

\section{Summary}

The aim of this study is to access the spatial distribution of hand dug wells and boreholes in Boroboro community of Atiba LGA in Oyo. This study was therefore used as a Spatial Decision Support System (SDSS) which is an aid to support decision making. Data set for the study included spatial and non-spatial data. Imagery of the study area Boroboro was downloaded via the Google Earth pro, geo-referenced and digitize in ArcGIS 10.3 from the various analyses. The various features were represented by symbols, well-structured database was created through proper design and construction faces using ArcGIS 10.3 for the implementation of the data analysis, queries were issued and buffering was done in respect to criteria for the location hand dug wells and boreholes. The data generated was analyzed through ArcGIS 10.3 software and the buffering of the boreholes and hand-dug wells were overlaid to know those who have access to both the boreholes and the hand dug well. The result shows as the community expands, the distance to the existing and available boreholes and hand dug wells increases. It is recommended government should assist in the provision of potable water through sitting of hand dug wells and boreholes with good depth in the study area.

\section{Conclusion}

GIS has been demonstrated as a tool capable of handling effective referenced problems. This research shows hand dug wells and boreholes were not evenly distributed in the study area. The central part of the community enjoys adequate access to water sources, as the community expands outward leaving the developing areas out of coverage as lack of accessibility and distance to existing the hand dug wells and boreholes.

\section{Recommendations}

Base on the outcome of this research, it is recommended government should assist in the provision of potable water through sitting of hand dug wells and boreholes with good depth in the study area. Opened Hand dug well should be cover, those that are not up to $18 \mathrm{~m}$ deep are not meant for the consumption because some of the hand dug wells failed to meet the $60 \mathrm{ft}$ depth standard required by the World Health Organization (WHO) and additional boreholes should be made available from the government for better living of the people. During dry season require depth should be dug so that potable water can be available year-round for the people living in the study area. It is also recommended that proper maintenance practice should be carried out periodically by the people as well to prolong the span of the borehole submersible pumps. Further research can be carry in the study area to include testing for the quality of the water assessed.

\section{References}

1. Audu HA Ehiorobo OJ (2015) Geospatial techniques in Water Distribution Network Mapping and Modelling in Warri Port Complex. Wisdom of the Ages to the Challenges of the Modern World, Sofia, Bulgaria.

2. World Bank Global Report on Population and Access to Quality Water (2002).

3. Anwuri OO, Lawrence H, Kurotamuno JP (2015) Mapping the Spatia Distribution of Water borehole facilities. Wisdom of the Ages to the Challenges of the Modern World, Sofia, Bulgaria.

4. Belolo B, Ojewumi OO (2010) GIS in distribution, assessment and evaluation of hand dug wells and boreholes. A case study of part of Oyo west Local Government. An unpublished GIS project in federal school of surveying, Oyo.

5. Sowton M (1991) Development of GIS related Activities at the ordinance survey Geographical Information System. Principles and application Longman, New York, USA.

6. Anayah F (2006) An assessment of the nitrate and chloride in the West Bank groundwater resources using GIS. An-Najah National University, Nablus, Palestine.

7. Falkenmark M, Lundqvist J, Widstrand C (1989) Macro-scale water scarcity requires micro-scale approaches. Natural Resources Forum 13: 258-267.

8. UNJMP (2008) UN Water annual report

9. Cunningham WP, Saigo Y, Coburn C (2005) Environmental Science - A global concern. McGraw Hill, Boston, Massachusetts, USA.

10. Elueze AA (1986) Petrology and Gold mineralization of the Amphibolites belt llesha area southwestern Nigeria. Geol En Mijbouw 65: 189-195.

11. Rahaman MA (1976) Review of the basement geology of the southwestern Nigeria. In: Geology of Nigeria, Elizabeth Publishing Co, Lagos, Nigeria, pp: 41-58.

12. Kufoniyi O (1998) Database Design and Creation. In: Principles and Application of GIS. Panaf Press, Lagos, Nigeria, pp: 50-60. 